\title{
Lapsuuden elinolojen yhteydet aikuisuuden hyvinvointiin
}

Suurimmalla osalla Suomessa syntyneistä lapsista ja nuorista menee hyvin, mutta...

- arviolta joka seitsemäs 25-vuotias nuori aikuinen on ilman toisen asteen tutkintoa (1)

- joka neljäs kärsii jonkin asteisesta mielenterveyden häiriöstä (2)

- nuorten työkyvyttömyyksistä mielenterveysperustaisia on jopa neljä viidestä (3)

- 16-24-vuotiaiden nuorten osalta työkyvyttömyyseläkkeellä olevien määrä on lisääntynyt, vaikka vastaavasti työikäisten määrä on vähentynyt (3).

Väitöstutkimukseni "Lapsuuden elinolojen yhteydet aikuisuuden hyvinvointiin" on tarina vuonna 1987 syntyneistä. Tuo kokonainen ikäluokka on elänyt voimakkaan murroksen aikaa. Heidän nuoreksi aikuiseksi kasvamistaan ovat varjostaneet varhaislapsuudessa 90-luvun alun syvä ja vaikea lama, taloudellisen itsenäistymisen vaiheessa 2000-luvun lopussa alkanut pidempi ja lievempi taantuma ja hyvinvointipalveluihin kohdistuneet leikkaukset 90-luvun alusta alkaen. Tässä väitöstutkimuksessa vuonna 1987-syntyneitä on seurattu rekisteri- ja tilastotiedon valossa.

Tutkin hyvinvoinnin riskitekijöitä, toisin sanoen niitä elinoloja, jotka ovat yhteydessä myöhempään hyvinvointiin - tai pikemminkin pahoinvointiin, hyvinvoinnin puutteeseen. Riskitekijät ovat tekijöitä, jotka väitöskirjatutkimukseni viitekehyksessä kasvattavat pahoinvoinnin mahdollisuutta ja kuormittavat lasta ja nuorta. Riskitekijät ovat kuitenkin vain kolikon toinen puoli. Vastavuoroisesti voidaan puhua suojaavista tekijöistä. Siinä missä riskitekijät painavat pinnan alle ja kuormittavat, niin suojaavat tekijät nostavat ja kannattelevat. Harvoin yksittäinen riskitekijä painaa kokonaan pinnan alle, sillä muut tekijät kannattelevat turvaverkon verkon lailla. Puhutaan pärjäävyydestä. Joskus yksittäinenkin riskitekijä tosin voi olla viimeinen pinnan alle vetävä voima, etenkin jos lapselle ja nuorelle on kasaantunut riskitekijöitä eikä turvaverkko enää kannattele. Suurilla aineistoilla löydetyt merkitykselliset hyvinvoinnin eroja selittävät riskitekijät ovat pieniä osia laajemmasta monimutkaisesta kokonaisuudesta. Yhden nuoren kohdalla riskitekijä ei kuitenkaan vääjäämättä tarkoita tapahtuman toteutumista syy-seuraussuhteen lailla, sillä jokaisen elämäntilanne on aina yksilöllinen. Väitöstutkimuksessani riskitekijät on luokiteltu yksilö-, perhe- ja koulutason tekijöihin. Näiden tekijöiden yhteyttä myöhempään nuoren aikuisuuden hyvinvointiin tutkittiin väitöstutkimuksessa sosiaaliepidemiologian näkökulmasta. Sosiaaliepidemiologiassa tutkitaan niitä sosiaalisia eli yhteiskunnallisia tekijöitä, joihin on mahdollisuus vaikuttaa palvelu- ja etuusjärjestelmän kautta. Biologiset tekijät ovat kuin talon kivijalka, niihin emme enää voi vaikuttaa. Ne on jätetty tarkastelun ulkopuolelle.

Turvaverkon rakentuessa lasta ja nuorta ympäröivät ympäristöt ovat avainasemassa. Perhe ja koulu nähdään ensisijaisina lasten kasvua ja kehitystä tukevina ympäristöinä. Lapsen varttuessa häneen vaikuttavat ympäristöt laajenevat samanaikaisesti. Urie Bronfenbrennerin (4) bioekologinen systeemiteoria käsittelee yksilön kehittymistä yhteiskunnan kokonaisvaltaiseksi jäseneksi. Teorian mukaan lapset ja nuoret elävät vuorovaikutuksessa ympäristöjensä kanssa. Lapset ja nuoret ovat esimerkiksi osa perhettä, osa kouluyhteisöä ja vielä laajemmin osa yhteiskuntaa. He oppivat yhteisön säännöt ja tavat. Loppuviimeinen nämä yhteisöt ovat enemmän kuin osiensa summa. Perhe on enemmän kuin perheenjäsenistä koostuva ruokakunta. Se on kuin lentokone, enemmän kuin osista koottu laite. Sillä on kyky lentää. Yleinen systeemiteoria tukeutuukin juuri tähän ajatukseen. Osien ja kokonaisuuden vuorovaikutuksessa systeemi, sanottakoon, että lapset osana perhettä, asettuu aina 
jonkinlaiseen tasapainoon. Tuota tasapainotilaa voivat kuormittaa monet tekijät.

Hyvinvoinnista puhuttaessa puhutaan tyypillisesti pahoinvoinnista. Hyvinvointi määritellään ongelmien ja hyvinvoinnin puutteiden kautta. Hyvinvointi on hyvin laaja käsite ja se on hankala määritellä tyhjentävästi. Pohjoismaisessa kontekstissa tukeudutaan usein Erik Allardtin (5) hyvinvointiteoriaan, jossa hyvinvointi jaetaan kolmeen hyvinvoinnin ulottuvuuteen; elintasoon, sosiaalisiin suhteisiin ja itsensä toteuttamiseen. Väitöstutkimuksessani keskityn elintasoulottuvuuteen. Elintasoulottuvuus perustuu aineellisiin resursseihin ja fysiologisiin tarpeisiin. Sitä on mitattu etupäässä koulutukseen ja terveyteen liittyvien tekijöiden kautta. Allardtin mukaan terveys on hyvinvoinnin perusedellytys. Se vaikuttaa esimerkiksi mahdollisuuteen kouluttautua.

Tutkimuksessani nuorten terveyttä ja koulutusta on tarkasteltu tarkemmin mielenterveyden ja koulutusasteen eli suoritettujen tutkintojen näkökulmasta. Sekä mielenterveyden häiriöistä että tutkinnoista on kirjattu paljon tietoa eri viranomaisrekistereihin. Esimerkiksi mielenterveyden häiriöistä on kirjattu asetetut mielenterveyden diagnoosit, käytetyt psyykenlääkkeet ja mielenterveysperustaiset työkyvyttömyydet. Koulutusasteesta on kirjattu nuorten suoritetut tutkinnot.

Vuonna 1987 syntyneistä ja heidän vanhemmistaan on kirjattu sosiaali- ja terveystietoja viranomaisrekistereihin vuosien aikana. Näitä viranomaisrekistereitä yhdistelemällä on koottu Terveyden ja hyvinvoinnin laitoksen (THL) Kansallinen syntymäkohortti 1987 -rekisteriaineisto. Se kattaa lähes kaikki 60000 Suomessa vuonna 1987 syntynyttä lasta. Kohorttiaineisto on koottu THL:n vuonna 1987 perustetun syntyneiden lasten rekisterin ympärille, mihin muiden kansallisten rekisteriviranomaisten tietoja on yhdistetty. Kansallinen syntymäkohortti onkin ainutlaatuinen näkymä yhden ikäluokan hyvinvointiin lähes kolmen vuosikymmenen ajalta.

Väitöstutkimukseni mukaan Suomessa elää joukko lapsia ja nuoria, joiden elämänkulku lapsuudesta aikuisuuteen on tavanomaisesta poikkeava. He tarvitsevat tukea kiinnittyäkseen yhteiskuntaan. Aineistossani joka neljännelle vuonna 1987 Suomessa syntyneelle oli asetettu joko mielenterveyden diagnoosi tai määrätty psyykenlääke 9-24-vuotiaana. Mielenterveyden häiriöistä johtuva työkyvyttömyys oli myönnetty lähes puolelletoista prosentille 16-24-vuotiaista ja joka kolmastoista nuori oli ilman toisen asteen tutkintoa 28-vuotiaana. Nuoret miehet - reilusti yli puolet - olivat naisia useammin ilman toisen asteen tutkintoa.

Tutkimus vahvisti aikaisemmin löydettyjen riskitekijöiden kuten sukupuolen, perheen suhteellisen köyhyyden ja vanhempien työkyvyttömyyksien yhteyden nuorten mielenterveysperustaisiin työkyvyttömyyksiin. Näiden tunnettujen ja vahvistettujen tutkimustulosten lisäksi tutkimus paljasti, että äidin ja isän työkyvyttömyydellä on itsenäiset yhteydet nuorten mielenterveysperustaisiin työkyvyttömyyksiin. Kuitenkin siten, että vain äidin mielenterveysperustainen työkyvyttömyys selittää eroja nuorten työkyvyttömyyksissä kaikilla nuorilla, mutta myös niillä nuorilla, joilla on todettu mielenterveyden häiriöitä.

Vaikkakin nuorten mielenterveysperustaisten työkyvyttömyyksien tekijät ovat varsin hyvin tiedossa, niin niiden väliset yhteydet eivät. Väitöstutkimus tunnisti, että vanhempien mielenterveyden häiriöiden ja nuorten mielenterveysperustaisen työkyvyttömyyden välisessä yhteydessä nuorten oma mielenterveyden häiriö näytti välittävän edellä mainitusta yhteydestä reilun kolmanneksen - enemmän kuin nuoren sosiaalinen huono-osaisuus. Sosiaalinen huono-osaisuus välitti yhteydestä reilun neljänneksen. Kokonaiskuva muuttui kuitenkin, kun yhteyksiä tarkasteltiin nuorten naisten ja miesten osalta erikseen; epäsuorat yhteydet mielenterveyden häiriöiden ja sosiaalisen huono-osaisuuden välittämänä olivat naisilla miehiä paljon voimakkaammat. Suorat yhteydet selittävät vain nuorten miesten työkyvyttömyyksiä.

Jo vuonna 2007 saksalaisessa kyselytutkimuksessa (6) löydettiin vanhempien vakavien somaattisten eli fyysisten sairauksien yhteys heidän lastensa mielenterveyden oireiden välillä. Väitöstutkimuksessani tutkittiin kansainvälisen tautiluokitusjärjestelmän tautiluokkien välistä yhteyttä lasten ja nuorten mielenterveyden häiriöihin. Tutkimus tunnisti jo aikeisemmin tunnistettujen tautiluokkien yhteyksiä, mutta myös uusia aikaisemmin tunnistamattomia. Tautiluokat jaoteltiin neljään luokkaan tautiluokan yleisyyden, keston ja syntymistavan mukaan; 1) äkillisesti alkaneisiin ja henkeä uhkaaviin, 2) pitkäkestoisiin, 3) tavanomaisiin ja 4) tautiluokkiin, joissa oli selittämättömiä oireita. 
Myös lyhyttä koulutuspolkua eli peruskoulun päättötodistuksen varassa olemista selittävät tunnetut yksilötason tekijät kuten mielenterveyden häiriö, koulumenestys, perheen suhteellinen köyhyys ja vanhempien matala koulutusaste, vahvistettiin väitöstutkimuksessa. Vaikka nämä tunnetut yksilötason tekijät oli huomioitu, koulutason tekijöistä hyvä luokkatyörauha näytti edistävän nuorten koulutuspolun jatkumista peruskoulun jälkeen. Työrauha nähdään osallisuusteorioiden valossa laajempana käsitteenä kuin kuri ja nuhde Mainittavaa on myös, että osallisuudesta, johon luokkatyörauha osallisuusteorioiden mukaan katsotaan kuuluvan, ei ole aikaisemmin lainkaan tehty pitkittäistutkimusta.

Peruskoulutuksen jälkeinen lyhyt koulutuspolku on osa laajempaa yhteiskunnallista keskustelua ja syrjäytymiskeskustelua, jossa koulutus ja etenkin terveys koulutuksen mahdollistajana nähdään ensisijaisina keinoina ehkäistä syrjäytymistä ja nostaa nuoria takaisin työmarkkinoille. Syrjäytyneiksi luokitellaan koulutuksen ja työelämän ulkopuoliset nuoret, joilla ei ole peruskoulutuksen jälkeistä koulutusta. On kuitenkin huomioitava, että syrjäytyminen ei ole pysyvä tila. Se on ajassa muuttuva; nuori voi yhtenä vuonna olla vailla koulutusta ja työtä, kun seuraavana vuonna tilanne voi olla jo toinen. Sanana syrjäytyminen on varsin leimaava, mutta jotta asioista voidaan puhua, on ne jollakin tasolla pysyttävä määrittelemään, jotta asiaan voidaan vaikuttaa. Koulutuksen ja työelämän ulkopuolelle jäämisen syynä ovat usein mielenterveysongelmat. Nuorten syrjäytyminen, nuorisotyöttömyys ja vaikeutuneet mielenterveysongelmat ja niistä johtuvat työkyvyttömyydet ovat ongelmallisia hyvinvointivaltion rakenteiden kannalta. Inhimillisen ja henkilökohtaisen tragedian lisäksi syrjäytyminen on myös suuri kansantaloudellinen kustannusrasite yhteiskunnalle eri korjaavien, ehkäisevien, hyvinvointia tukevien palveluiden käytön ja menetettyjen verotulojen muodossa. Vuonna 2017 ilmestyneen Valtioneuvoston Hyvä elämä - turvallinen arki -julkaisun (7) johtopäätöksissä laajeneva ja monimuotoinen syrjäytyminen on nimetty Suomen keskeisimmäksi sisäisen turvallisuuden haasteeksi.

Onkin pystyttävä tarjoamaan ajankohtaista tietoa hyvinvoinnin sosiaalisista riskitekijöistä ja suojaavista tekijöistä etenkin sosiaali- ja terveyspolitiikan kuntapäättäjille, kansanedustajille ja ministereille tiedolla johtamisen välineiksi mutta myös asiantuntijoille, tutkijoille ja erilaisille organisaatioille, järjestöille ja säätiöille. Päättäjien tehtävänä on kehittää palvelu- ja etujärjestelmää tarpeita vastaavaksi, sillä edelleenkään kunnissa ei ehkäisevää ja hyvinvointia tukevaa työtä ole saatu lamaa edeltävälle tasolle, ja korjaavien palveluiden menot nousevat jatkuvasti. Palvelujärjestelmä ei myöskään vastaa ihmisten todellisiin tarpeisiin, ongelmat ovat tänä päivänä monitahoisia ja kokonaisuuden huomioiminen nykyisessä sektoripalvelujärjestelmässä on vaikeaa ja hidasta. Palvelujärjestelmien tulisi tukea lasten ja nuorten elämänhallintataitoja ja mahdollisuuksia olla aktiivinen toimija omaan elämäänsä liittyvissä päätöksissä.

Pohjoismaisen hyvinvointivaltion yksi erityispiirre on universaalisuus, jonka mukaan kaikki kansalaiset ovat oikeutettuja sosiaaliturvaan ja julkisiin palveluihin. Sixten Korkmanin (8) mukaan hyvinvointipalvelujen tarjonnan pitäisi olla niin laajaa ja laadultaan hyvää, että myös hyvätuloiset käyttäisivät julkisia palveluita, jotta yhteiskunnan jakautuminen eriarvoisiin luokkiin voitaisiin välttää. Taloudellinen eriarvoisuus on kuitenkin lisääntynyt yhteiskunnassamme, vaikka yksi hyvinvointivaltion tavoitteista on pyrkiä edistämään kansalaisten tasa-arvoisia mahdollisuuksia heidän lähtökohdistaan huolimatta, vähentämään yksilöiden välisiä tuloeroja ja torjumaan köyhyyttä. Vuoden 2019 Elinkeinoelämän valtuuskunnan asennekyselytutkimuksen (9) mukaan 64 prosenttia vastaajista oli sitä mieltä, että tuloerot väestöryhmien välillä ovat kasvaneet liian suuriksi.

Ristikarin ja kollegoiden (10) mukaan lapsuuden aikainen perheen suhteellinen köyhyys on yhteydessä nuorten myöhempään huono-osaisuuteen. Tutkimuksessa käytettiin huono-osaisuuden osoittimena mielenterveyden häiriöitä ja heikkoa taloudellista tilannetta nuoressa aikuisuudessa. Tutkimuksen tulosten mukaan hyväkään koulumenestys ei täysin tasoita lapsuuden aikaisen köyhyyden yhteyttä lapsen myöhempään huono-osaisuuteen. Lapsiperheiden tukeminen on ensiarvoisen tärkeää, ja erityisesti sosiaalisessa ja taloudellisessa ahdingossa olevia perheitä on tuettava. Toisaalta, jotta koulutus-, terveys- ja sosiaalipolitiikka olisi tehokasta, sen tulee koskea yleisesti kaikkia lapsiperheitä, eikä vain riskiryhmään kuuluvia. 
Yhteiskuntapolitiikka on tukeutunut perinteiseen aikuisuuden elinoloja korostavaan sosiaaliepidemiologiaan. Lisäksi palvelujärjestelmässä perheen ja perheenjäsenten ongelmia on yleensä hoidettu itsenäisesti ilman näkemystä perheen vaikeuksista. Esimerkiksi aikuispalveluissa ei ole aikaisemmin järjestelmällisesti huomioitu asiakkaiden lasten tarpeita. Väitöstutkimukseni tulosten mukaan vanhempien mielenterveyden häiriöiden yhteys heidän lastensa masennus- ja ahdistushäiriöperustaisiin työkyvyttömyyksiin ei ole yksioikoinen. Sen sijaan tuohon yhteyteen voidaan vaikuttaa toimilla tukien nuorten mielenterveyttä ja sosiaalisia ympäristöjä. Ennakoivat ja tukevat toimet tulisi kohdistaa mielenterveyden häiriöistä kärsiville ja sosiaalisesti huonoosaisille nuorille, mutta erityisesti perheisiin, joissa mielenterveyden häiriöistä kärsivillä vanhemmilla on pieniä lapsia. Myös vanhempien somaattiset sairaudet kuormittavat perheitä, kuten väitöstutkimuksessa todettiin. Tulokset auttavat ymmärtämään, mitä vanhempien somaattisia sairauksia tulisi nostaa esille potentiaalisten huolenaiheiden ja tulevaisuuden ongelmien tekijöinä, kun somaattisesti sairailla vanhemmilla on lapsia huolehdittavana. Yleisesti ottaen voidaan sanoa, että vanhempien hoidossa, oli vanhemmalla sitten psykiatrinen tai somaattinen sairaus, lapset tulisi ottaa enenevissä määrin huomioon ja tukea heidän normaalia psyykkistä kehitystään, silloin kun vanhempien kyky huolehtia lapsen hoidosta ja kasvatuksesta arvioidaan heikentyneen. Lasten mukaanotto vanhempien hoitojärjestelyihin on jo laillinen vaatimus Suomessa terveydenhuoltolain mukaan.

Tehokkaiden ja tutkimusnäyttöön perustuvien interventiomenetelmien käyttöönotto ja ylläpito vaatii resursseja, mutta se olisi panostus tulevaisuuteen. Nobelin taloustieteen palkinnon vuonna 2000 saaneen yhdysvaltalaisen James Heckmanin mukaan (11) yhden dollarin panostus lasten varhaiskasvatukseen niissä perheissä, joissa on ongelmia, antaisi jopa kahdeksankertaisen tuoton, jos varat kohdennetaan oikein. On epäselvää, paljonko tuotto voisi olla pohjoismaisessa kontekstissa, mutta varmaa on, että oikeinkohdennettuna panostukset voisivat olla tuottoisia. Näin ollen ehkäisevä toiminta kalliisiin korjaaviin toimenpiteisiin verrattuna vähentäisi myöhemmin julkisen talouden rahoitusongelmia
Sujuva arki kotona ja kodin ulkopuolella, erityisesti varhaiskasvatuksessa ja koulussa, voi suojata lasta ja nuorta silloinkin, kun kotona on ongelmia. Väitöstutkimukseni tulokset osoittavat, että peruskoulun ulkopuolisten asioiden ohella nuoriso- ja koulutuspoliittiseen keskusteluun on otettava peruskoulun sisäinen näkökulma. Yksilöivää hyvinvointityötä tulee täydentää ehkäisevällä otteella koulukulttuurin rakentamisessa. On otettava huomioon vuorovaikutussuhteet ja yhteisölliset tukevat tekijät. Anna-Maija Poikkeuksen ja kollegoiden (12) mukaan Alkuportaat-seurantatutkimuksessa on huomattu, että opettajan myönteinen tuki lisää oppilaiden opiskelumotivaatiota alakoulussa. Heidän mukaansa opettajan ja oppilaan vuorovaikutuksella on enemmän vaikutusta oppimistuloksiin kuin opetuksen rakenteellisilla tekijöillä, kuten oppimateriaalin laadulla ja luokkakoolla. Väitöstutkimukseni tulosten mukaan luokkatyörauhan edistäminen on tärkeä yhteiskunta- ja koulutuspoliittinen tavoite. Tukemalla luokkatyörauhaa sen laajemmassa merkityksessä, yhtenä osallisuuden osoittimena, nuorten koulutuspolut voivat pidentyä. Työrauhalla tarkoitetaan tutkimuksessa kohtaamista ja välittämistä, vuorovaikutusta opettajan ja oppilaan välillä eikä ainoastaan sääntöjä ja kuria, kuten tavallisesti ajatellaan.

Pääviestini on, että nuorten pahoinvoinnin kasvua ei ole saatu hillittyä. Voivottelun sijaan keskustelu syrjäytyneistä ja huono-osaisista lapsista tulee kääntää siihen suuntaan, kuinka voimme tukea lapsia ja nuoria elämänkulun nivelvaiheissa. Tarvitaan tutkittua tietoa riskitekijöistä, koska lasten ja nuorten tukemisen on perustuttava tutkimustietoon ja vaikuttavuuteen. Rekistereistä ja tilastoista nousevan tiedon avulla päättäjät voivat tarjota ja kohdentaa saatavissa olevia, vaikuttavia, riittäviä, ehkäiseviä ja oikeaaikaisia terveys- ja hyvinvointipalveluita. On huomioitava, että palveluiden lisääntyminen ei välttämättä lisää hyvinvointia. Varsinkaan niin kauan, kun sektoripalvelujärjestelmä ei perustu yhteisövaikuttavuuden ajatukselle - sille, että esimerkiksi palvelujärjestelmä, koulu, varhaiskasvatus ja järjestöt keskustelevat keskenään lapsen kokonaisvaltaisen hyvinvoinnin näkökulmasta sujuvan arjen takaamiseksi. Tutkimusperustaista tietoa tarvitaan hyvinvointiongelmien ja -vajeiden ehkäisevän työn ja painopisteiden 
määrittelyn tueksi, sosiaalipoliittisen päätöksenteon avuksi, yhteiskunnan palvelujärjestelmän parantamiseksi ja oikea-aikaisen toiminnan kohdistamiseksi.

"On helpompi rakentaa vahvoja lapsia kuin korjata rikkinäisiä aikuisia.” Douglass (esim. 13)

\section{LÄHTEET:}

1. Ristikari T, Törmäkangas L, Lappi A ym. Suomi nuorten kasvuympäristönä. 25 ikävuoden seuranta vuonna 1987 syntyneistä. Raportti 9. Helsinki: Terveyden ja hyvinvoinnin laitos ja nuorisotutkimusverkosto: 2016.

2. Patel V, Flisher AJ, Hetrick S ym. Mental health of young people: A global public-health challenge. The Lancet 2007; 369 (9569): 1302-1313. Doi: 10.1016/S0140-6736(07)60368-7

3. Suomen virallinen tilasto (SVT). Suomen työkyvyttömyyseläkkeensaajat sairauden mukaan. Helsinki: Kela: 2019. Luettu 11.6.2019. http://raportit.kela.fi/linkki/69852606

4. Bronfenbrenner U. The ecology of human development: Experiments by nature and design. Cambridge, MA: Harvard University Press: 1979.

5. Allardt E. Dimensions of welfare in comparative Scandinavian study. Research reports - Research group for comparative sociology; no. 9. Helsinki: Helsingin yliopisto: 1975.

6. Barkmann C, Romer G, Watson M ym. Parental physical illness as a risk for psychosocial maladjustment in children and adolescents: Epidemiological findings from a national survey in Germany. Psychosomatics; 2007; 48(6): 476-481.

7. Valtioneuvosto. Hyvä elämä - turvallinen arki. Valtioneuvoston periaatepäätös sisäisen turvallisuuden strategiasta 5.10.2017. Sisäministeriön julkaisu 15. Helsinki: Sisäministeriö: 2017.
8. Korkman S. Onko hyvinvointivaltiolla tulevaisuutta? EVA raportti. Helsinki: Elinkeinoelämän valtuuskunta: 2011, 10, 26-27.

9. Elinkeinoelämän valtuuskunta. EVAn Arvopankki - Tuloerot väestöryhmien välillä ovat kasvaneet maassamme liian suuriksi. Helsinki: Eva: 2019. Luettu 11.6.2019. https:/www.eva.fi/arvopankki/ perusnakyma.php?q=3952

10. Ristikari T, Merikukka M, Savinetti NF ym. Path modelling of children's life outcomes: the 1987 Finnish Birth Cohort. Journal of Public Health 2018; 27, 761-769.

Doi: $10.1007 / \mathrm{s} 10389-018-0997-2$

11. Heckman JJ. Skill formation and the economics of investing in disadvantaged children. Science 2006; 312(5782), 1900-1902.

Doi: $10.1126 /$ science. 1128898

12. Poikkeus A-M, Rasku-Puttonen H, Lerkkanen MK. ym. Osallistava koulu syrjäytymisen ehkäisijänä. Teoksessa L. Vähäkylä \& J. Reivinen (toim.), Ketä kiinnostaa? Lasten ja nuorten hyvinvointi ja syrjäytyminen. Helsinki: Suomen Akatemia: 2013, 111-120.

13. Mapp S, Gabel SG. It is easier to build strong children than to repair broken men. Journal of Human Rights and Social Work 2019; 4, 145-146. Doi:10.1007/s41134-019-00106-z

\section{Marko MerikukKa}

FT (kansanterveystiede), FM (tilastotiede)

Tiedeasiantuntija

Itsenäisyyden jublavuoden lastensäätiö sr. (Itla)

Filsofian maisteri Marko Merikukan väitöskirja "Lapsuuden elinolojen ybteydet aikuisuuden byvinvointiin - Kansallinen syntymäkohortti 1987 -rekisteriaineistolla" tarkastettiin Oulun yliopiston lääketieteellisessä tiedekunnassa 25.9.2020. Vastaväittäjänä toimi dosentti Tomi Oinas Jyväskylän yliopistosta ja kustoksena professori Marjo Renko Itä-Suomen yliopistosta. 